\title{
Formation of clusters in cultural heritage - strategies for optimizing resources in museums
}

\author{
Héctor Moreno - Mendoza \\ Faculty of Economics Business and Tourism, \\ University of Las Palmas de Gran Canaria, Las Palmas de Gran Canaria, Spain \\ Agustín Santana - Talavera \\ Istur Instituto de Investigación Social y Turismo, University of La Laguna, \\ San Cristóbal de La Laguna, Spain, and \\ José Molina - González \\ Service of Computing Statistic and Data Bank, Istac Canary Island Statistics Institute, \\ Gobierno de Canarias, Santa Cruz de Tenerife, Spain
}

\begin{abstract}
Purpose - The purpose of this study is to affirm that it is possible to segment visitors of cultural heritage into homogeneous groups according to a series of characteristics to detect the variables that have statistical significance to identify visitor clusters.

Design/methodology/approach - Four case studies were selected, where a total of 500 questionnaires were made to visitors. The authors proceeded with cluster analysis using SPSS software to differentiate visitor segments. Four groups of visitors were first identified and which have subsequently been reduced to three, according to several factors.

Findings - The main contributions of this paper are: (1) the segment to which each one of the determinants of the cultural tourism product is dedicated; (2) the variable object of the analysis, i.e. the formation of visitor segments; and (3) the inclusion of less studied variables such as type of accommodation contracted, treatment offered in the museums or entrance price.

Research limitations/implications - The analysis has been developed in different museums, with different management models, in a specific place. However, the results are generalizable to other places and to other institutions that manage cultural heritage. The implications are management strategies for a sustainable cultural development in institutions of tourism and heritage.

Practical implications - From a practical point of view, the results are useful for cultural managers, travel agencies, tour operators, tourism companies or political offices, among others, because they generate new ideas and strategies focused on maximizing the use of the resources of cultural institutions.

Social implications - For both local and non-local agents, the knowledge of the factors that make up the groups of visitors in the heritage sites represents a strategy in aspects of marketing, promotion and distribution, thus generating capacities for the different intermediaries, and the possibility of negotiating lower prices with better benefits. It is also possible to create new products destined for other publics.
\end{abstract}

Originality/value - The study is original because this has not been published.

Keywords Museum offer, Visit factors, Museums, Segmentation, Cultural tourism product

Paper type Research paper

\footnotetext{
Acknowledgments: To the museums that have researched in this study, and to the staff that has helped the researchers to carry out this research: Painted Cave, Néstor Museum, Cultural Project of Community Development of La Aldea and Cenobio de Valerón.

Funding: "Tourist Intelligence for responsible marine tourism” (ProdID2017010123) co-funded by
Agencia Canaria de Investigación, Innovación y Sociedad de la Información through a funding Research
and Development Project regarding Strategy for Intelligent Specialization in the Canary Islands and the
Operative Program of FEDER Canarias 2014-2020.

Funding: "Tourist Intelligence for responsible marine tourism" (ProdID2017010123) co-funded by
Agencia Canaria de Investigación, Innovación y Sociedad de la Información through a funding Research
and Development Project regarding Strategy for Intelligent Specialization in the Canary Islands and the
Operative Program of FEDER Canarias 2014-2020.

Funding: "Tourist Intelligence for responsible marine tourism" (ProdID2017010123) co-funded by
Agencia Canaria de Investigación, Innovación y Sociedad de la Información through a funding Research
and Development Project regarding Strategy for Intelligent Specialization in the Canary Islands and the
Operative Program of FEDER Canarias 2014-2020.

Funding: "Tourist Intelligence for responsible marine tourism" (ProdID2017010123) co-funded by
Agencia Canaria de Investigación, Innovación y Sociedad de la Información through a funding Research
and Development Project regarding Strategy for Intelligent Specialization in the Canary Islands and the
Operative Program of FEDER Canarias 2014-2020.
}

Clusters in cultural heritage
Received 15 December 2019
Revised 6 July 2020
22 December 2020
7 January 2021 Accepted 29 January 2021 


\section{Introduction}

Museums have to face the challenge of dealing with mass tourism as a sample of the general public (Pijbes, 2015). The museum product includes both the building and its lighting, means of attending visitors, methods to stimulate interest and commitment to the visitor (Goulding, 1999). All these aspects affect visitor perception. Museum perception is based on effective communication, as well as the ability to build images, transmit information, attract visitors, through social exchange, offer more texts or apply more visual methods to improve the tourist product. The visitor of cultural tourism may be understood, according to Chen and Rahman (2018), as a specific segment in a wide field of the heritage tourism phenomenon. In a competitive tourism market, we need to understand the nature of the experience of the museum visit (Figure 1).

There is increasing pressure on museums to expand their appeal, to attract a wider and more diverse audience, as well as to improve the implementation of measures based on managing customer satisfaction (Backman and Nilsson, 2018). To a large extent, such innovations must be carried out by the heritage staff itself, from below and not so much at an administration level. Falk and Dierking (2012) propose a model of interactive experience for the visitor, which should be activated by the staff of cultural institutions. They suggest that the visitor's involvement is not necessarily passive, but rather a dynamic process that includes experiences, before, during and after the visit. A visit is oriented to the visitors, as, according to Mateos Rusillo (2012), they are the priority public, as they give it meaning.

Museum visitors, as Sheng and Cheng (2012) put it, usually expect the institution, and in part its activators (staff), to offer them a simple and enjoyable experience. These institutions, especially those in the public sector, have been slow to respond to visitors' suggestions. They fail to take into account the growing pressure to be more competitive and self-sufficient (Plaček et al., 2017).

This paper delves into the formation of clusters among visitors of heritage sites, assuming a series of recommendations made by experts regarding destination planning (Alvarez et al., 2016). These recommendations apply to managing cultural heritage, particularly in museums and interpretation centers.

Figure 1.

Localization map of the case studies
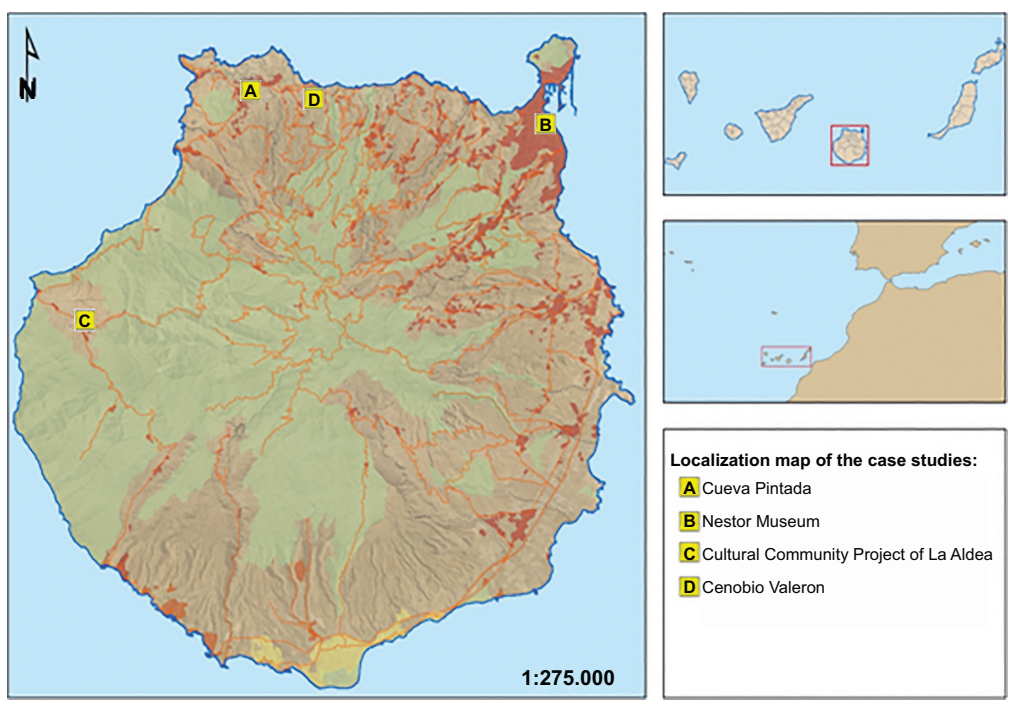

Localization map of the case studies:

A Cueva Pintada

B Nestor Museum

C Cultural Community Project of La Aldea

D Cenobio Valeron

Note(s): Original research findings 
Our review of the literature detected a gap regarding the variables that constitute the visitor segments in museums to establish specific attention strategies. Our research endeavours to help fill the gap. The decision affects several parties: visitor, museum, destination and other tourist actors. Clusters are understood as "natural" groups, suitable and with practical use. These groups differ in different and significant ways (Gürel and Nielsen, 2019).

With a sample of 500 visitors, and making questionnaires, the four management models are considered: public dependent, public with management autonomy, non-profit and private, through case studies, to obtain results and finally reach conclusions.

The tourism experience, as a strategy and as part of the offer, has been studied from the marketing perspective (Rindova et al., 2011), and more recently, the experience in guided tours in historical cities has been deepened (Yavuz Çetinkaya and Oter, 2015). Brida et al. (2017), as background to this research, analyze learning and motivation through factors in the duration of the visit to the museum, using a logit and with a case study methodology, concluding that motivation affects visit duration, understanding time as an indicator of learning. Coudounaris and Sthapit (2017) also investigate the tourist experience and the intention of the visitor's behaviour in a museum, through questionnaires.

The studies carried out do not go into depth regarding the factors that determine the segments of the visitors, to attend to the specific needs, and once the antecedents are analyzed, the need to identify which are priority is detected. Thus, we propose as an objective to detect the variables that have statistical significance to identify visitor clusters. The purpose of this study is also to affirm that it is possible to segment visitors of cultural heritage into homogeneous groups according to a series of variables.

The study data come from the 500 questionnaires carried out in the four case studies. To respond to the purpose and objective of this research, a valid cluster was made to determine the variables, which allowed us to identify the sample subgroups with different experience patterns. Then, the study segments are identified. Finally, it reduces the number of segments to provide greater significance.

The study concludes with the practical implications derived from the results, for the management and tourist promotion of the museums that intend to carry out strategies of specialization of the public.

\section{The development of clusters to optimize the cultural tourism product}

The role of the visitor is increasingly important in shaping the cultural-museum product. Fernández and Fernández (2012, p. 122) affirm that there is a "new museology", which is the community that marks and consecrates the raison d'etre of these institutions as an instrument of cultural, social and economic development. Mihaly Csikszentmihalyi (1992) offers five interrelated conclusions concerning the relationship of aesthetic experience in art museums: (1) it is productive and beneficial, (2) requires prior knowledge, (3) is consistent with the constructivist theories of museums, (4) is or should be the main mission of any museum and (5) can be provided through specific programmes and contexts. On the other hand, Goulding (2000), carries out a qualitative study to outline a social, cognitive and environmental approach to the behaviour of museum visitors.

Introducing information on educational practices, according to Lankford (2002), the authority in the interpretation is shared and does not only fall into the hands of the spectator. It may offer experiences that are both culturally responsible and personally significant. There has been a recent trend in museum education that emphasizes the idea that the viewer's individual interpretation is the best result of the encounter with the museum contents, from this culturalist conception of art and interpretation, the work with visitors should not be limited to the expression of unique personal responses.

With projects labelled as sustainable or responsible and promoted, exogenously (governmental or non-governmental agencies) or endogenous (local institutions or 
residents) with knowledge of what others do, capital and reasons are mobilized that defend cultural-environmental awareness. From this vision, it is possible to offer unique and satisfactory experiences, to set positive and lasting memories in the visitor through visual consumption, interactive participation or selfless help without harming the cultural environment (Santana Talavera, 2008). These aspects are applicable in the field of museums, in this sense, museums perform functions of conservation, research, communication and exhibition of the tangible and intangible heritage of humanity and its environment for the purposes of education, study and enjoyment (ICOM, 2007). In a greater area of responsibility, governance in museums plays an important role in the relationships between the stakeholders of the local community (Moreno Mendoza et al., 2019).

In studies into visitor attitude, Falk and Dierking (1992) proposed an interactive model of experience. They find that a visitor's experience is not necessarily passive. The physical environment of the museums (the physical context) is influenced both the personal and social context, which resonates in the experience of the visitor. These authors suggest that visitor experience is not a static state (Antón et al., 2018), but rather a dynamic process that includes experiences before, during and after the visit. Their model aims to clarify the aspects that influence users' experience. Visitors' opinions go through a responsible vision of the tourist product on offer, considering both social aspects (visitor demand) and the interests of a competitive market (museum profitability). Another author claims that visitors are always somewhat active in their pursuit of interpretation, deciding whether or not to read a label or play with an interactive. But, when you invite visitors to retrieve interpretative material rather than laying it out, it gives them a kind of participatory power. They choose what to reveal and explore (Simon, 2010, p. 37).

Taking the museum visit experience as an interaction of three contexts: personal, social and physical, the literature review does not establish general variables to study the experience in the context of museums. Several authors describe the experience in terms of some variables that mainly involve learning and enjoyment (Belaën, 2005), but that also address personal variables, expectations, motives and the museographic context and its environment. The government of Spain's Permanent Laboratory of Museum Public proposes several variables to measure the Positive Museum Experience Scale (EMP, from the Spanish title), (Ministry of Education, Culture and Sport, 2013), offers a global score (from 0 to 39 points) indicating the intensity of the positive experience that the person has when leaving the museum, based on the main domains and variables that seem to influence this experience (general, environmental, affective, physical, etc.). These variables have been taken as reference and adapted to the possibility of measurement in the context of research, determining the variables that are presented in the methodology presented.

Adie and Hall (2016) carry out a comparative analysis of three case studies of cultural sites: Independence Hall (USA), Studenica Monastery (Serbia) and Archaeological Site of Volubilos (Morocco), and compare, through surveys, the profile of visitors to each of the cases, to detect general trends of visitor characteristics. The significance and satisfaction in the museum experience is the product of a fusion of the past and new events of the museum itself (Graburn, 1977); more recently, it is understood that in the field of museums, the visitor experience is a key factor to ensure the sustainability of the museum and even its own survival. In most references to experience, reference is made to a consideration of importance for the competitiveness of the cultural institution (Aquilino et al., 2019).

This increase in competitiveness involves increasing responsibility for the cultural product (Marchetti and Valente, 2017). González and Soliguer (2013), through interviews with experts, try to define whether responsible tourism is a social movement (which seeks sustainability) or if it is a niche market (to create products based on social sustainability). As a conclusion, they determine that the double meaning coexists. The authors also believe that the demand for responsible tourism will increase in the future. That is why, it is of interest for this study to address aspects of responsibility in the field of museums. 
The creation of clusters (Hair et al., 2013) in the tourism product is explained by the fact that groupings generate value, which increases as the results of the activity (in this museum study) are directed to final consumers. Market opportunities have also been explored in the field of museums through improved practices and impact analysis of clusters (Tien, 2010). Museum visitor behaviour may be studied using data produced by mobile sensors (Martella et al., 2017). The sources consulted are oriented towards other areas, e.g. cluster analysis in the context of marinas as destinations (Parker and Vural, 2016), or in the area of tourism and hospitality (T\&H) industry (Chhetri et al., 2017), but the scope of museums has not been broadened, which is why we need to cover this gap with the analysis of the public characteristics of these cultural institutions.

\section{Methodology and case studies}

Questionnaires were made to visitors (Table 3), and a subsequent analysis was performed with SPSS (statistical package for the social sciences). The basic application of this program is to analyze scientific data related with the social science. These data can be used for market research, surveys, data mining, etc. (Green and Salkind, 2016). Its content offers researchers the possibility of statistically analyzing, through a cluster analysis, visitors' profiles and detect patterns in the characteristics of the visit to the museums spaces.

For this study, a questionnaire was designed taking a qualitative approach according to the proposal of the experience by Shaw and Ivens (2005), who combined open and closed answers, an aspect we adopted for this study. The main reasons for the visit were also analyzed, and the differences between visitors' opinions in the different study cases were compared. The numbers of visitors in each case appear in Table 1. The methodology of case studies has been chosen, because following Simons (2011, p. 42) "The case study is an exhaustive investigation and from multiple perspectives of the complexity and uniqueness of a particular project, policy, institution, program or system in a real context”.

The methodology of case studies is important for this work because four heritage sites have been selected with different management models, and through this, an exhaustive study of each case and from different perspectives (the visitor and the researcher) is established. The strategy allows us to justify the assumption that the general is reflected in the particular. Four case studies have been selected for this paper. The four case studies are located in a tourist region, specifically on the island of Gran Canaria (Spain).

\subsection{Description of the cases}

Case A: Cueva Pintada Archaeological Museum and Park. The museum opened to the public in 2006, to visit the museum, the town, the pre-Hispanic farmhouse and the Cave, forming part of an aboriginal troglodyte group. Located in the town of Gáldar, is publicly owned with the provision of services to several private companies.

Case B: Néstor Museum. The institution was inaugurated in 1956, with the donation of part of the artist's work by some members of his family, heritage that has been enriched

\begin{tabular}{lrccccc}
\hline $\begin{array}{l}\text { Visits } \\
(2019)\end{array}$ & Total & $\begin{array}{c}\text { Schools and groups } \\
\%\end{array}$ & $\begin{array}{c}\text { Regional } \\
\%\end{array}$ & $\begin{array}{c}\text { National } \\
\%\end{array}$ & $\begin{array}{c}\text { International } \\
\%\end{array}$ & $\begin{array}{c}\text { Activities } \\
\%\end{array}$ \\
\hline Cueva & 71,024 & 21 & 39 & 12 & 25 & 3 \\
Néstor & 15,267 & 60 & 20 & 8 & 12 & 0 \\
Aldea & 3,200 & 60 & 15 & 10 & 15 & 0 \\
Cenobio & 21,731 & 7 & 15 & 15 & 63 & 0
\end{tabular}

Note(s): Original research findings

Table 1.

Distribution of visitors in the case studies 
JCHMSD

\begin{tabular}{|c|c|c|c|}
\hline Descriptor & Variables & Definition & Value \\
\hline 1 & Country & Home country & $\begin{array}{l}1 \text { Resident, } 2 \text { Spain, } 3 \text { Germany, } 4 \\
\text { Italy, } 5 \text { France, } 6 \text { UK, } 7 \text { Others, } 9 \text { no } \\
\text { response }\end{array}$ \\
\hline 2 & Accommodation & Type of accommodation & $\begin{array}{l}1 \text { Only accommodation, } 2 \\
\text { accommodation and breakfast, } 3 \text { half } \\
\text { board, } 4 \text { all inclusive, } 9 \text { no response }\end{array}$ \\
\hline 1 & Resident & Local island resident & 0 No, 1 yes, 9 no response \\
\hline 2 & Arrival & How did you arrive? & $\begin{array}{l}1 \text { Day trip, } 2 \text { package holiday, } 3 \text { hire } \\
\text { car, } 4 \text { public Transport, } 5 \text { others, } 9 \text { no } \\
\text { response }\end{array}$ \\
\hline 2 & Who & $\begin{array}{l}\text { With whom did you visit the } \\
\text { museum? }\end{array}$ & $\begin{array}{l}1 \text { Alone, } 2 \text { couple, } 3 \text { children, } 4 \text { partner } \\
\text { and children, } 5 \text { adults, } 6 \text { student } \\
\text { group, } 7 \text { organized group, } 8 \text { others, } 9 \\
\text { no response }\end{array}$ \\
\hline 2 & Age & Age group (years) & $\begin{array}{l}1:<18,2: 18-30,3: 31-50,4: 41-70,5: \\
>70,9: \text { No response }\end{array}$ \\
\hline 2 & Sex & Gender & 1 Masculine, 2 feminine, 9 no response \\
\hline 3 & Motivation & Reason for visit & $\begin{array}{l}1 \text { Attraction, } 2 \text { hobby, } 3 \text { knowledge, } 4 \\
\text { interest, } 5 \text { work, } 6 \text { understanding, } 7 \\
\text { see different things, } 8 \text { others, } 9 \text { no } \\
\text { response }\end{array}$ \\
\hline 2 & Knowledge & $\begin{array}{l}\text { How did you come to know of the } \\
\text { museum? }\end{array}$ & $\begin{array}{l}1 \text { Web, } 2 \text { brochure, } 3 \text { internet, } 4 \text { advert } \\
5 \text { travel agency, } 6 \text { travel agency, } 7 \\
\text { study centre, } 8 \text { others, } 9 \text { no response }\end{array}$ \\
\hline 4 & Guided tour & Have you been on a guided tour? & 0 No, 1 yes, 9 no response \\
\hline 3 & Characteristics & $\begin{array}{l}\text { Evaluation of museum } \\
\text { characteristics: treatment, } \\
\text { atmosphere, presentation, clarity, } \\
\text { learning possibility, content, } \\
\text { accessibility, sign for entrance } \\
\text { tickets, services }\end{array}$ & $\begin{array}{l}\text { Evaluation from } 1 \text { (very poor) to } 10 \\
\text { (very good) }\end{array}$ \\
\hline 4 & Quality - price & Relationship of quality and Price & $\begin{array}{l}1 \text { Good, } 2 \text { reasonable, } 3 \text { inexpensive, } 9 \\
\text { no response }\end{array}$ \\
\hline 4 & Enjoyment & $\begin{array}{l}\text { Positive aspects that the visitor } \\
\text { would highlight }\end{array}$ & $\begin{array}{l}1 \text { Exhibition, } 2 \text { communication and } \\
\text { information, } 3 \text { functioning, } 4 \\
\text { maintenance, } 5 \text { installation, } 6 \text { staff, } 7 \\
\text { promotion, } 8 \text { others, } 9 \text { no response }\end{array}$ \\
\hline 4 & Non-enjoyment & $\begin{array}{l}\text { Negative aspects that the visitor } \\
\text { would highlight }\end{array}$ & $\begin{array}{l}1 \text { Exhibition, } 2 \text { communication and } \\
\text { information, } 3 \text { functioning, } 4 \\
\text { maintenance, } 5 \text { installation, } 6 \text { staff, } 7 \\
\text { promotion, } 8 \text { others, } 9 \text { no response }\end{array}$ \\
\hline 4 & Suggestions & $\begin{array}{l}\text { Improvement proposals indicated } \\
\text { by the visitor }\end{array}$ & $\begin{array}{l}1 \text { Exhibition, } 2 \text { communication and } \\
\text { information, } 3 \text { functioning, } 4 \\
\text { maintenance, } 5 \text { installation, } 6 \text { staff, } 7 \\
\text { promotion, } 8 \text { others, } 9 \text { no response }\end{array}$ \\
\hline
\end{tabular}

Table 2.

Variables used in the questionnaire

with private donations and subsequent acquisitions. Belonging to the City of Las Palmas de Gran Canaria, but managed by a board.

Case C: Community Development Project of the township of La Aldea, it is a non-profit museum model. Created as a didactic and ethnographic activity since 1980, volunteers offer guided tours to the 14 museums that make up the project located in La Aldea of San Nicolás, considered the most important living museum in Europe. 
Target

population

Visitors to museums, with diverse motivation

Period 29 July 2017-21 December 2017

Sampling TOTAL: 500 visitors

Cueva Pintada Archaeological Museum and Park (150 questionnaires) - 30\%

Néstor Museum (120 questionnaires) - 24\%

La Aldea Community Project (100 questionnaires) - $26 \%$

Cenobio de Valerón (130 questionnaires) - 20\%

Sample error

Sample

$<5.00 \%$ with a reliability coefficient of $95 \%$

500 (free random Data collection

sampling)

system
PAPI. Individualized questionnaires carried out at the museum exit
Table 3.

Technical data sheet of the field work and structure of the simple

Case D: Cenobio de Valerón. It is a collective barn, formed by 298 compartments distributed in eight floors, built and used by the aborigines of the island of Gran Canaria until the conquest at the end of the 15th century. Managed by a private company, but of public ownership. Cenobio is located in Santa María de Guía de Gran Canaria.

For this study, an example of an archaeological museum and park, a museum of fine arts, an ethnographic community development project and an archaeological interpretation centre were selected to approach the governance of the island's cultural heritage, to complete the whole of management models. These management cases are developed in the methodology of our investigation, taking into account cultural heritage management models (Lord and Lord, 1998). These models are: (1) organically dependent, (2) dependent with management autonomy, (3) non-profit organization and 4) private entity.

For this study, we have used the practice of grounded theory. Its aim is to construct an analysis scheme with high levels of abstraction on a specific social phenomenon, deductive and inductive. The grounded theory, first associated with Glaser and Strauss (1967) and then with Strauss and Corbin (1990), attempts to understand the opinions and interpretations of the participants based on how they "construct" their worlds, to generate a theory. The qualitative interpretive framework is currently the most widely used in the social sciences (Simons, 2011). It has a constructivist vision, so Charmaz (2006) proposes that data and theories are constructed from the relationships and interactions that emerged during the investigation. In this paper, we have followed the mechanisms proposed by Thomas and James (2006), which establish the reinvention of the grounded theory, focusing on the salient aspects of the qualitative information obtained, being cautious with the interpretation of the results.

That is why, in this research the fundamental theory approach has been used to attain the stated aim. The application of this approach is applied by analyzing the questionnaires, when the researchers detect a saturation in the open answers, through the repetition of information (the frequencies of the open "like" questions, "did not like it" and "suggestions" are taken as a reference), decide the time to stop data collection and begin the analysis of the information in the questionnaires.

\subsection{Visitors questionnaires}

Once it was decided what information was necessary to meet objectives and affirm hypotheses, and which was the most appropriate method of obtaining this information, it was crucial to identify from whom data should be collected. Amis (2005) proposes that there is a need to identify participants capable of providing adequate levels of knowledge for the 
phenomena studied. In most cases, the population on which it is intended to study is too broad to collect data from each individual, so a sample must be made. Intentional sampling has been carried out because "this type of sampling is characterized by obtaining representative samples, which is what the researchers look for in the opinion about the product of the visitors of the museums".

The aforementioned visitor questionnaire, carried out for this research, was carried out after visits to each of the study cases (museums) and is divided into three parts with 14 questions: (A) sociodemographic data (P.1) nationality, P.2 accommodation, P.3 how it arrives, P.4 with whom, P.5 age and P.6 gender); (B) Perception-assessment (P.7 reason for the visit, P.8 as known), P.9 assessment guided visit, P.10 assessment aspects of the museum and P.11 value for money), the last questions; section $(\mathrm{C})$ aspects to highlight, are the most open, and with possibilities of infinite answers (P 0.12 Is there anything you would like to highlight (especially liked) about this museum? Q.13 Is there something you would like to highlight (did not like) about this museum, and Q.14 do you have any suggestions to improve this museum?. A total of 500 questionnaires were carried out (distributed as in Table 1), adapting the number of them to the case study.

To analyze the content and proceed to the coding of the last three, due to the wide possibility of answers, as the questions were open, eight categories have been established in terms of their content, taking as reference the aspects of the museum that establishes the Permanent Laboratory of Public of Museums (Ministry of Education, Culture and Sport, 2013, pp. 95-98): (1) exhibition, (2) communication and information, (3) operation, (4) conservation, (5) facilities, (6) personal, (7) promotion and (8) others. The categories highlighted according to the resulting clusters are shown in Table 4.

\subsection{Cluster analysis}

Krantz et al. (2009) use cluster analysis to explore the audience of museums and determine how it applies to these cultural institutions. In this study, we have applied it to the four proposed study cases; the results obtained are shown in Table 4.

Cluster analysis determines natural groups from large datasets, creating similar groups that differ significantly from one another. This research has resulted in four groups of visitors, who differ by various characteristics, and whose purpose is to provide institutions with improvement in meeting their demand.

The steps taken for the analysis follow those of Krantz et al. (2009) and are based on: (1) creating a series of variables (determined by the museum experience) (Table 2); (2) application of the questionnaire; respecting the minimum sample of 300 indicated by Randi Korn and Associates (2009), we have made 500 (Table 3); (3) decide how many groups to establish; (4) perform the analysis (Table 5); (5) determine if the results are admissible, it is considered adequate between three and five groups, we have established four, which subsequently have been reduced to three (Table 6), with its corresponding ANOVA test to check the initial objective (Table 7).

Table 4.

Age and gender distribution of the surveyed visitors

$$
\begin{gathered}
\text { <18 years: } 7 \% \\
\text { 18-30 years: } 16 \% \\
31-50 \text { years: } 37 \% \\
51-70 \text { years: } 32 \% \\
>70 \text { years: } 6 \% \\
\text { NR: } 2 \%
\end{gathered}
$$

Gender

Female 55\%

Male $44 \%$

NR: $1 \%$

Note(s): Original research data 


\begin{tabular}{|c|c|c|c|c|c|}
\hline Variable/cluster & 1 & 2 & 3 & 4 & Clusters 1 \\
\hline Resident & No & No & Yes & Yes & heritag \\
\hline Accommodation & All included & Bed and breakfast & Resident & Resident & \\
\hline With whom & $\begin{array}{l}\text { Organized } \\
\text { group }\end{array}$ & Partner with children & $\begin{array}{l}\text { Organized } \\
\text { group }\end{array}$ & Adults & \\
\hline Knowledge & Travel agent & Adverts & Study centre & Others & \\
\hline Guided visit & & Yes & Yes & Yes & \\
\hline What you liked & Functioning & $\begin{array}{l}\text { Communication and } \\
\text { information }\end{array}$ & Functioning & $\begin{array}{l}\text { Communication and } \\
\text { information }\end{array}$ & \\
\hline What you did not like & Promotion & - & Presentation & - & \\
\hline Suggestions & Functioning & Exhibition & Promotion & Presentation & \\
\hline TOTAL & 54 & 207 & 85 & 154 & Clust \\
\hline \multicolumn{5}{|c|}{ Note(s): Original research data } & \\
\hline
\end{tabular}

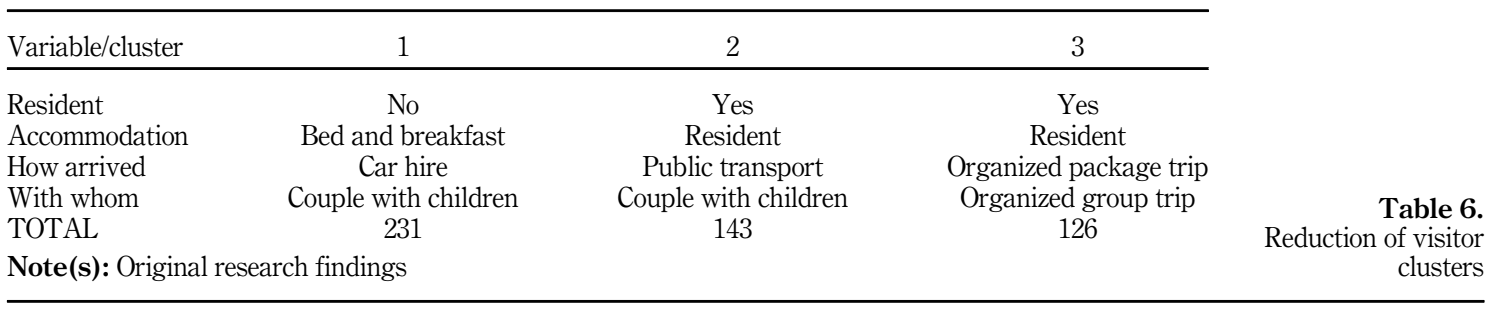

\begin{tabular}{|c|c|c|c|c|c|c|c|}
\hline Variable & $\begin{array}{c}\text { Cluster } \\
\text { Root mean square }\end{array}$ & $\mathrm{Gl}$ & Root mean square & $\begin{array}{l}\text { Error } \\
\text { Gl }\end{array}$ & $\mathrm{F}$ & Sig & \\
\hline Resident & 26,175 & 2 & 0.122 & 497 & 213,990 & 0.000 & \\
\hline Lodging(1;6) & 914,356 & 2 & 0.728 & 497 & 1256,626 & 0.000 & \\
\hline $\operatorname{Arrival}(1 ; 5)$ & 187,507 & 2 & 1.693 & 497 & 110,774 & 0.000 & \\
\hline With whom $(1 ; 8)$ & 618,163 & 2 & 1.532 & 497 & 403,463 & 0.00 & ANOVA test of mean \\
\hline \multicolumn{7}{|c|}{ Note(s): Original research data } & clusters \\
\hline
\end{tabular}

It was expected that the geographic profile, the sociodemographic profile and the characteristics of perception - evaluation would vary among the clusters, which was validated through the chi-square test $\left(\chi^{2}\right)$.

\section{Results}

With the data obtained in the 500 questionnaires carried out (see the characteristics of the sample in Table 3), in the chosen heritage sites, and their treatment with the statistical program SPSS version 24.0, differences are obtained in terms of age and gender of the surveyed visitors (Table 4) and later the cluster analysis is carried out (Table 5). Age distribution in the sample of each one of the study cases was taken into account, to obtain representation in each assigned category. By the same token, gender representation balance was sought. To happen of everything, there were small differences in these representations. To carry out the analysis, the sample had to be coded, and different tests were carried out with the data obtained, until the veracity of the results was verified. 
Two main steps have been taken in this section: (1) cluster analysis and identification of four segments where the variables of each of the clusters are differentiated and (2) subsequent ANOVA analysis to relate the variables.

The K-media analysis indicates that the four groups are representative due to the number of individuals that make up each one. The results have determined two groups of residents and two other groups of non-residents; the differences are centred on the type of accommodation, with whom the museum visits were carried out, how they came to know of the museum and the aspects they liked most, what they liked least and suggestions. The analysis has determined three groups (2,3 and 4), in which the visitors make the guided tour, being able to establish consumer profiles of guided visits.

\subsection{Reduction to three groups of visitors}

Although valid results have been obtained by establishing four clusters, and being representative of $N$, it has been decided to adjust the cluster number even more and reduce it to three (Table 6), to determine if there are significant differences. Analyzed the centres of the clusters, the similarity of the variables with respect to the cluster is determined. In this way, it is intended to specify the possibility of establishing more specific strategies or implications for those stakeholders that make up the field of tourism and museums (visitors, managers, administrations, commercials, etc.). There are certain differences in the determination of four clusters, and in this case, there are four variables that differentiate the established groups. In a first group (non-residents), the obvious difference is the type of accommodation and the means to get to the museum, where the rental car predominates. In the other two clusters (residents), the main difference is the way to get to the museum and with whom they go. While a group arrives by public transport (for their own interest, or students who determine a visit by hiring this medium), the other group arrives at the museum through organized travel packages (associations, groups of friends, non-governmental organizations (NGOs), educational institutions, etc.). Another difference between the residents is that the first group visits the museum with their partner and children (public transport or sometimes private), and the second arrives with an organized group that planned the visit beforehand, and normally, in almost all cases are complemented by other additional activities (lunch, visit to other museums or attractions of interest, performance of leisure activities, etc.).

For the reduction of clusters, the ANOVA test (Table 7), through the Sig, we see how in the determined variables they are significant, although they have been reduced to four, regarding the five of the model of the four clusters.

Although the variables change according to whether we establish three or four subgroups, it is possible to determine which ones determine the constitution of clusters. As tests have been performed introducing and eliminating variables until finding the valid models, the values established in this analysis can be confirmed. Despite the small difference in how many clusters, it is determined that the variables that make up the clusters are the results in Table 6, (type of accommodation, being a resident, treatment offered in the museum, accessibility of the museum) and while we intend to further reduce the subgroups, we must pay attention to the variables in Table 7, (being a resident, type of accommodation, how you arrived at the museum and who you have visited the museum with).

\section{Discussion}

Research studies concerning museums or heritage sites usually focus on visitor motivation (Falk and Dierking, 2012; Eidelman et al., 2014) or on financial strategies (Siu et al., 2013). Our paper proposes a model that detects what factors segment the visitors, and with that, form homogenous groups. 
The findings also indicate the significant effect this would have for cultural institutions to take into account factors indicated as visitor priorities. However, there is no significant link between the visitor's country of origin and the factors found. Our results indicate the effectiveness of adapting techniques for knowledge of the visitor profile and creating links in the construction of hospitality and caring relationships, sometimes personalized, with the visitors.

\subsection{Implications for the management of the museum}

Our study shows that, apart from the principle of reciprocity, the relational investment efforts of a service provider with its clients, in this case museums, add values (i.e. knowledge and relational values) to visitors. It is recommended that service providers pay attention to the creation of value in service processes. A paradigm shift focused on values rather than the goods to be commercialized (Vargo and Lusch, 2008), in which they adopt a more holistic perspective when considering not only economic gains or losses, but also relational strengths, for services offered, which are experiential in nature (Ekinci et al., 2008). Therefore, managers must continually understand what values are treasured by their visitors. In addition, with this model, museums have the capacity to attract potential visitors, taking into account the different factors analyzed. It is possible to confirm the affirmation of the existence of levels of consciousness in groups of visitors to cultural heritage (Adie et al., 2018), in this case in museums.

There are several examples of museums that do questionnaires for visitors on the way out of their visits, and this serves to know the profile of visitors and to improve museum strategies (the already studied case of the Cueva Pintada). There are some others like Red House Museums and Gardens (Christchurch, UK), Scottish National Gallery of Modern Art (Edinburgh, UK), DDR Museum (Berlin, Germany) or National Museum (Prague, Czechia).

\subsection{Implications for the tourist destination}

The characteristics of the destination also influence the displacement model (Ekinci et al., 2008); according to these authors, diversity of landscapes and environments allows the distribution of tourist packages avoiding the overlap of places to visit in a destination. This principle is applicable to this study, in such a way that the variety of characteristics offered by the heritage site, taking into account the determining factors of the museum offer, would avoid the overlapping of similar offers, in such a way that the promotion campaigns adapt to specific audiences.

This study of clusters reaffirms the research that ensures the interaction between clustershared capabilities and firm-specific capabilities in exploration and exploitation to obtain two types of firm organizational innovation (Camisón et al., 2017) and also reviews the importance of creating clusters for effective destination management (Chin et al., 2017).

\subsection{Implications for stakeholders (local residents and non-local)}

For both local and non-local agents, the knowledge of the factors that make up the groups of visitors in the heritage sites represents a strategy in aspects of marketing, promotion and distribution, thus generating capacities for the different intermediaries of accommodation, commerce, transportation, etc., and the possibility of negotiating lower prices with better benefits. It is also possible to create new products destined for other publics.

For tour operators, it is interesting to know the factors that determine the clusters of visitors to the heritage sites, to plan their activities according to the tourism package that they want to offer, in addition to understanding which components are capable of offering differentiation with respect to other attractions. It is possible to affirm with this study that the 
analysis of clusters applied to the local community is a tool to evaluate the impacts of tourism activity (Vareiro et al., 2013).

With the valid variables obtained from the clusters, it can be determined that there is a basic segmentation of visitors, differentiated between residents and non-residents. Although both consume the same cultural product (museum or temporary exhibition), there is no repetition of the visit by non-residents. Being this way, two complementary offers can be attended: on the one hand, the permanent one (fixed exhibition), and on the other hand the punctual one (temporary exhibitions and cultural events). The most effective seems to be to focus efforts on making the resident repeat the visit and the non-resident have a satisfactory experience that contributes to the good assessment of the destination.

\section{Conclusions}

The main contributions of this paper, from an academic point of view, are threefold: (1) the segment to which each one of the determinants of the cultural tourism product is dedicated; (2) the variable object of the analysis, i.e. the formation of visitor segments; and (3) the inclusion of less studied variables such as type of accommodation contracted, treatment offered in the museums or entrance price.

From a practical point of view, the results are useful for cultural managers, travel agencies, tour operators, tourism companies or political offices, among others, because they generate new ideas and strategies focused on maximizing the use of the resources of cultural institutions.

The offer of language-specific guided tours implies a necessary adaptation that addresses cultural differences beyond translation. This implies an adaptation of the museum communication system that affects the museum guide, the information on panels, screens and brochures. The task is made easier with the use of mobile technologies, which does not replace the personal and versatile interaction of the guide. This interaction between the museum and non-resident visitors is more effective when their stay is longer and the contracted accommodation is a hotel but not an all-inclusive one. Although apparently the variables "accommodation" or "how arrived" are far from museum management, it is appreciated that in the development of the image construction strategy and motivation for the visit they can be very relevant. This can be measured and, where appropriate, verified through the "knowledge", supporting those means whose results are most effective (travel agencies, social networks, brochures, etc.).

Other aspects that may influence the design of the strategy are the way of visiting the museum (alone, with a couple, in a group) and the means of transportation. Through both (generally crossing both variables) information is obtained to guide the optimization of visiting times, tours of rooms or exhibitions, support in audio-visual technologies. With this, it is possible, e.g. to establish specific recommendations for the organization of the visit, without making major changes in the exhibitions.

This analysis should help museum managers, and by extension ,cultural sites, to carry out strategies, both to attract casual travellers looking for leisure and entertainment, and to residents who are looking for a new product or service. It does not contrast this with the traditional mission of the museums, where the culture is conserved and transmitted to the visitors while they are exhibited.

It would be interesting to carry out an in-depth investigation of the rest of the variables that complete this study. For example, it may be worth knowing if residents spend more or less than non-residents. It would also be interesting to analyze how clusters behave regarding what is on offer. For example, to ascertain why residents visit one museum and not another and the justifications for choosing that visit. 
The findings strongly support the theory of segmentation and positioning the cultural product (Cuadrado and Fresquet, 1999). However, this study is limited by some elements. It proposes a mechanism to detect the relationship between the groups and the factors of the visitors with arguments of value creation. Future studies could explore other possible link mechanisms between visitors and cultural attractions. For example, consumers can identify themselves with the institution by maintaining relationships with them and determine the factors to consume other products offered by the institution, such as temporary exhibitions or the institution's published materials.

Although the factor analysis showed concrete support for the association between the main variables, the data were cross-sectional, which prevented us from inferring causal relationships. Although we try to minimize these inconveniences by interviewing real clients immediately after they visit the museums, the data do not fully reflect the active and real-time reactions of the clients. In-depth interviews, focus groups and surveys would determine "a vision of the consumption process" (Ostrom et al., 2010, p. 26). Therefore, there is an opportunity to reconfirm these research results and further explore these relationships with other alternatives, including the guided tour model, trying to introduce other factors, e.g. level of studies, income, repeat visitor or estimated visit times.

While our results focus on museums and the four existing management models have been taken into account, it can be said that according to the methodology applied, it is possible to generalize the findings. Though they may be limited in context, it suggests future research that will adopt a more rigorous sampling method to guarantee models.

\section{References}

Adie, B.A. and Hall, C.M. (2016), "Who visits World Heritage? A comparative analysis of three cultural sites”, Journal of Heritage Tourism, Vol. 12 No. 1, pp. 1-14.

Adie, B.A., Hall, C.M. and Prayag, G. (2018), "World Heritage as a placebo brand: a comparative analysis of three sites and marketing implications", Journal of Sustainable Tourism, Vol. 26 No. 3, pp. 399-415.

Alvarez, M.D., Yuksel, A. and Go, F. (Eds), (2016), Heritage Tourism Destinations: Preservation, Communication and Development, CABI, Oxfordshire and Boston.

Amis, J. (2005), "Investigating for case study research", in Andrews, D.L. (Eds), Qualitative Methods in Sports Studies, Berg, Oxford.

Antón, C., Camarero, C. and Garrido, M.J. (2018), "Exploring the experience value of museum visitors as a co-creation process", Current Issues in Tourism, Vol. 21 No. 12, pp. 1406-1425.

Aquilino, L., Armenski, T. and Wise, N. (2019), "Assessing the competitiveness of matera and the basilicata region (Italy) ahead of the 2019 European capital of culture”, Tourism and Hospitality Research, Vol. 19 No. 4, pp. 503-517.

Backman, M. and Nilsson, P. (2018), "The role of cultural heritage in attracting skilled individuals", Journal of Cultural Economics, Vol. 42 No. 1, pp. 111-138.

Belaën, F. (2005), "Línmersion dans les musées de science: médiation ou seduction?", Cultur el musées, Vol. 5, pp. 91-110.

Brida, J.G., Nogare, C.D. and Scuderi, R. (2017), "Learning at the museum: factors influencing visit length", Tourism Economics, Vol. 23 No. 2, pp. 281-294.

Camisón, C., Forés, B. and Boronat-Navarro, M. (2017), "Cluster and firm-specific antecedents of organizational innovation", Current Issues in Tourism, Vol. 20 No. 6, pp. 617-646.

Charmaz, K. (2006), Constructing Grounded Theory: A Practical Guide through Qualitative Analysis, Sage, Londres.
Clusters in cultural heritage 
Chen, H. and Rahman, I. (2018), "Cultural tourism: an analysis of engagement, cultural contact, memorable tourism experience and destination loyalty", Tourism Management Perspectives, Vol. 26, pp. 153-163.

Chhetri, A., Chhetri, P., Arrowsmith, C. and Corcoran, J. (2017), "Modelling tourism and hospitality employment clusters: a spatial econometric approach", Tourism Geographies, Vol. 19 No. 3, pp. 398-424.

Chin, W.L., Haddock-Fraser, J. and Hampton, M.P. (2017), "Destination competitiveness: evidence from Bali”, Current Issues in Tourism, Vol. 20 No. 12, pp. 1265-1289.

Coudounaris, D.N. and Sthapit, E. (2017), "Antecedents of memorable tourism experience related to behavioral intentions", Psychology and Marketing, Vol. 34 No. 12, pp. 1084-1093.

Csikszentmihalyi, M. (1992), Flow: The Psychology of Happiness, Rider Press, London.

Cuadrado, M. and Frasquet, M. (1999), "Segmentation of cinema audiences: an exploratory study applied to young consumers", Journal of Cultural Economics, Vol. 23 No. 4, pp. 257-267.

Eidelman, J., Roustan, M. and Goldstein, B. (2014), El museo y sus públicos. El visitante tiene la palabra, Editorial Ariel, Barcelona.

Ekinci, Y., Dawes, P.L. and Massey, G.R. (2008), "An extended model of the antecedents and consequences of consumer satisfaction for hospitality services", European Journal of Marketing, Vol. 42 Nos 1/2, pp. 35-68.

Falk, J.H. and Dierking, L.D. (1992), The Museum Experience, Whalesback Books, Washington DC.

Falk, J.H. and Dierking, L.D. (2012), Museum Experience Revisited, Left Coast Press, California.

Fernández, L.A. and y Fernández, I.M.G. (2012), Nueva museología: planteamientos y retos para el futuro, Alianza, Madrid.

Glaser, B. and Strauss, A. (1967), The Discovery Grounded Theory: Strategies for Qualitative Inquiry, Aldin, Chicago.

González Reverté, F. and Soliguer Guix, A. (2013), El turismo responsable en España a debate. ¿Movimiento de transformación social o nuevo producto turístico emergente? Investigaciones Turísticas, Universidad de Alicante, enero - junio, Vol. 5.

Goulding, C. (1999), "Interpretation and presentation", in Leask, A. and Yeoman, I. (Eds), Heritage Visitor Attractions: An Operations Management Perspective, Casell, London, pp. 54-68.

Goulding, C. (2000), "The museum environment and the visitor experience", European Journal of Marketing, Vol. 34 Nos 3/4, pp. 261-278.

Graburn, N. (1977), “The museum and the visitor experience”, Roundtable Reports, Vol. 2 No. 4, pp. 1-5.

Green, S.B. and Salkind, N.J. (2016), Using SPSS for Windows and Macintosh, Books a La Carte, University of Kansas, Pearson.

Gürel, E. and Nielsen, A. (2019), “Art museum visitor segments: evidence from Italy on omnivores and highbrow univores", International Journal of Arts Management, Vol. 21 No. 2, pp. 55-69.

Hair, J.F., Black, W.C., Babin, B.J., Anderson, R.E. and Tatham, R.L. (2013), Multivariate Data Analysis, 7 th ed, Pearson Prentice hall, Edinburgh.

ICOM (2007), "Museum definition", available at: http://icom.museum/the-vision/museum-definition/ Consulted24denovember2017.

Krantz, A., Korn, R. and Menninger, M. (2009), "Rethinking museum visitors: using K? Means cluster Analysis to explore a museum's audience. Curator”, Museums Journal, Vol. 52 No. 4, pp. 363-374.

Lankford, E.L. (2002), "Aesthetic experience in constructivist museums", Journal of Aesthetic Education, Vol. 36 No. 2, pp. 140-153.

Lord, B. and Lord, G.D. (1998), Manual de gestión de museos, Editorial Ariel, Barcelona. 
Marchetti, E. and Valente, A. (2017), "What a tangible digital installation for museums can offer to autistic children and their teachers", Autism Spectrum Disorders: Breakthroughs in Research and Practice: Breakthroughs in Research and Practice, Vol. 144.

Martella, C., Miraglia, A., Frost, J., Cattani, M. and van Steen, M. (2017), "Visualizing, clustering, and predicting the behavior of museum visitors", Pervasive and Mobile Computing, Vol. 38, pp. 430-443.

Mateos Rusillo, S.M. (2012), Manual de comunicación para museos y atractivos patrimoniales, Ediciones Trea, Gijón.

Ministerio de Educación, Cultura y Deporte (2013), Conociendo a nuestros visitantes. La Experiencia de la visita al museo. Secretaría General Técnica, Centro de Publicaciones. Ministerio de Educación, Cultura y Deporte, Madrid.

Moreno-Mendoza, H., Santana-Talavera, A. and J León, C. (2019), "Stakeholders of cultural heritage as responsible institutional tourism product management agents", Sustainability, Vol. 11 No. 19, p. 5192.

Ostrom, A.L., Bitner, M.J., Brown, S.W., Burkhard, K.A., Goul, M., Smith-Daniels, V., Demirkan, H. and Rabinovich, E. (2010), "Moving forward and making a difference: research priorities for the science of service", Journal of Service Research, Vol. 13 No. 1, pp. 4-36.

Paker, N. and Vural, C.A. (2016), "Customer segmentation for marinas: evaluating marinas as destinations", Tourism Management, Vol. 56, pp. 156-171.

Pijbes, W. (2015), El reto del museo es sobrevivir a una sociedad miope, El País, 30 Agosto 2015. Consulted 26 November 2017, available at: http://cultura.elpais.com/cultura/2015/07/10/ actualidad/1436538682_989447.html.

Plaček, M., Půček, M.J. and Šilhánková, V. (2017), "New trends in the strategic management of museums in the Czech Republic", Museum Management and Curatorship, Vol. 32 No. 4, pp. 302-318.

Randi Korn and Associantes, Inc (2009), Audience Research: Exploring Family Visitors to Art Museums, San Francisco Museum of Modern Arte, San Francisco, CA, available at: www.informal.science.org Consulted 20 november 2017.

Rindova, V., Dalpiaz, E. and Ravasi, D. (2011), "A cultural quest: a study of organizational use of new cultural resources in strategy formation", Organization Science, Vol. 22 No. 2, pp. 413-431.

Santana Talavera, A. (2008), "El turismo cultural. ¿Un negocio responsable?”, Estudios y Perspectivas en Turismo, Vol. 17 No. 4, pp. 294-318.

Shaw, C. and Ivens, J. (2005), Building Great Customer Experiences, Palgrave Macmillan, Basingstoke.

Sheng, C.W. and Chen, M.C. (2012), "A study of experience expectations of museum visitors", Tourism Management, Vol. 33 No. 1, pp. 53-60.

Simon, N. (2010), "The participatory museum", Museum, Vol. 2.0, pp. 37-39.

Simons, H. (2011), El estudio de caso: Teoría y práctica, Ediciones Morata, Madrid.

Siu, N.Y.M., Zhang, T.J.F., Dong, P. and Kwan, H.Y. (2013), "New service bonds and customer value in customer relationship management: the case of museum visitors", Tourism Management, Vol. 36, pp. 293-303.

Straus, A. and Corbin, J. (1990), Basics of Qualitative Research. Grounded Theory Procedures and Techniques, California.

Thomas, G. and James, D. (2006), "Reinventing grounded theory: some questions about theory, ground and discovery", British Educational Research Journal, Vol. 32 No. 6, pp. 767-795.

Tien, C.C. (2010), "The formation and impact of museum clusters: two case studies in Taiwan", Museum Management and Curatorship, Vol. 25 No. 1, pp. 69-85. 
Vareiro, L.M.D.C., Remoaldo, P.C. and Cadima Ribeiro, J.A. (2013), "Residents' perceptions of tourism impacts in Guimarães (Portugal): a cluster analysis", Current Issues in Tourism, Vol. 16 No. 6, pp. 535-551.

Vargo, S.L. and Lusch, R.F. (2008), "Service-dominant logic: continuing the evolution", Journal of the Academy of Marketing Science, Vol. 36 No. 1, pp. 1-10.

Yavuz Çetinkaya, M. and Öter, Z. (2015), "Sustainable valorization of cultural heritage via tour guides: Turkish case of Ephesus ancient city", PASOS : Revista de Turismo y Patrimonio Cultural, Vol. 13 No. 6, pp. 1403-1404.

\section{Corresponding author}

Héctor Moreno - Mendoza can be contacted at: hectormormen@gmail.com

For instructions on how to order reprints of this article, please visit our website: www.emeraldgrouppublishing.com/licensing/reprints.htm Or contact us for further details: permissions@emeraldinsight.com 